\title{
AUTOMOTIVE SERVICE INDUSTRY NEEDS OF AUTOTRONIC COMPETENCIES AND THOSE PREPARED BY THE EDUCATION
}

\author{
Wagiran and Yudha Ari Purnama \\ Mechanical Engineering Education Department, Faculty of Engineering, \\ Universitas Negeri Yogyakarta, Indonesia
}

\begin{abstract}
This study aims to formulate competencies in autotronics specifically in the cluster of Vehicle Control System (VCS) needed by the automotive service industry (ASI) and its relevance to those taught at Vocational Schools (VSs). Employing a survey method, this research is a quantitative study involving owners, managers, heads of workshops, and service managers of 10 ASI and educators from VSs offering autotronic expertise competencies. Data were collected through questionnaires, structured interviews, observation, and documentation study, and were analyzed descriptively. The results reveal that, of the 30 VCS competency units (CUs), 4 are both needed by ASI and taught at VSs, 11 are required by ASI but not studied at VSs, another CU is not needed by ASI but introduced at VSs, and the other 14 CUs are neither required by ASI nor trained at VSs.
\end{abstract}

Keywords: Autotronics, competencies, and vocational school.

Cite this Article: Wagiran and Yudha Ari Purnama, Automotive Service Industry Needs of Autotronic Competencies and those Prepared by the Education. International Journal of Mechanical Engineering and Technology. 11(4), 2020, pp. 34-43. https://iaeme.com/Home/issue/IJMET?Volume $=11 \&$ Issue $=4$

\section{INTRODUCTION}

Automotive technology has developed rapidly as technology and business disruption is introduced in the 21 st Century. This development has been accelerated by the presence of the fourth Industrial Revolution (IR 4.0) marked by extraordinary enhancement in terms of artificial intelligence, robotics, the Internet of things (IoT), autonomous vehicles, 3-D printing, nanotechnology, biotechnology, materials science, energy storage, and quantum computing [1]. Everywhere people can easily encounter mobile, super-computing, intelligent robots, self-driving cars, neuro-technologic brain enhancements, and genetic editing. Evidence of these dramatic changes is all around and turns out with exponential speed [2]. Just as phones got smart, so are cars, and they do not quite think, but will respond and remind. Cars on the road are being equipped with danger-warning applications, traffic information services, and host of infotainment features and increased safety features as well [3]. 
In regard to this, the automotive engineering industry is an commercial enterprise that continues to experience rapid development, starting from manufacturing cars with a conventional system that is mechanical in nature to those dominated by electronic systems that are analog and digital. Even in the future there may appear cars that are intelligent enough to be able to configure itself with the driver automatically. "By 2025, the vehicle will be sophisticated enough to configure itself to a driver and other occuparts" [4].

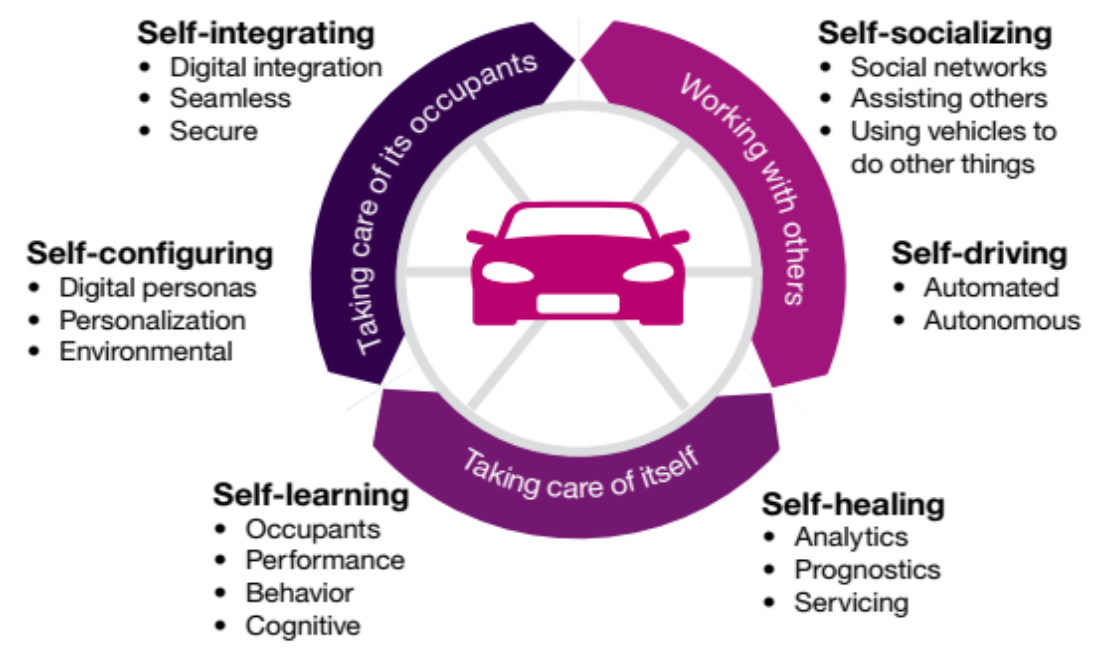

Figure 1 Main functions of cars based on electronic systems

(Source: IBM Institute for Business Value Analysis, www.ibm.com/downloads/cas/4JEQ0DN1)

The sub-sectors of the field of automatic engineering emerge on the basis of the development of electronic control systems increasingly being installed in motorized vehicles. Since the discovery of semiconductor materials in the era of the $60 \mathrm{~s}$ and the outgrowth of information technology better known as the digital era or the era of computerization, the electronic control system in all fields has been growing rapidly, including in the motorized vehicles. The increasing desire and demand of humans for safety, comfort, and ease of driving go hands in hands with the more developed electronic system in motor vehicles. In addition, the modification of electronic systems in motor vehicles also initiates the first step in the automotive engineering industry to move towards automobiles running fully automatic operations and electric-fueled cars.

Some enhancements in the automotive field, especially autotronics, undoubtedly have consequences for the automotive service industry (ASI) to always be able to serve the needs of consumers in dealing with various kinds of problems and maintenance of autotronic systems. To perform these tasks, naturally employees are expected to upgrade their competencies to catch up with the robust development of the future autotronic technology.

In the context of workforce preparation, vocational education (VE) especially Vocational Schools (VSs) plays a strategic role in preparing middle-level workforce candidates in this field. This is inseparable from the VE purpose, namely to prepare students to enter the workforce [5] [6] [7] [8] or education for the workforce [9] [10]. VE graduates are expected to have competencies according to the employment needs and be able to adapt to various characteristics of changes. Associated with the challenges of the 21 st Century and IR 4.0, VSs should present learning that can equip graduates who are innovative, inventive, self-motivated and self-directed, generate creative problem solvers facing increasingly complex global problems, having digital literacy and higher-order thinking skills. In other words, three very essential competencies to possess include learning and innovation skills; information, media, and technology skills; and life and career skills [11] [12]. 
Relevance is the keyword for the implementation of VE, but unfortunately, mismatch is still a major problem [13] [14] [15], as seen in the autotronics field of expertise. This is possibly complexly aggravated by the lack of research conducted to investigate the relevance of learning in VSs with the needs for competencies in the researched field. Hence, this study seeks to formulate the autotronic competencies in the VCS cluster needed by the automotive service industry and enumerate those taught in VSs to see how relevant both are. In detail, this research answers the following main questions.

- What is the formulation of middle-level employees' autotronic competencies in the VCS cluster based on the national VE guidelines?

- What is the description of middle-level employees' autotronic competencies in the VCS cluster as required by the automotive service industry?

- How relevant are the middle-level employees' autotronic competencies in the VCS cluster as taught in VSs with those required by the automotive service industry?

Competencies, as referred to as in this study, can be interpreted as the ability mastered by someone to enter the workforce. This is in line with the ideas suggested by some studies [16] [17] [18] [19] which reveal that competencies encompass the dimensions of knowledge, skills and attitude needed by the world of work. DeSeCo Project [20] asserts that competency is more than just knowledge and skills, as it involves the ability to meet complex demands, by drawing and mobilizing psychosocial resources, including skills and attitudes. While from its urgency, Gagnon [21] states that competency is the key to today's world of education.

The competency units (CUs) formulated in the field of autotronics engineering, based on the synthesis of the Indonesian National Work Competency Standards (SKKNI), National Qualification Framework (KKNI), and Vocational Schools Basic-Core Competencies (KI$\mathrm{KD}$ ), are classified into five main clusters or key functions, namely (1) Basics of Autotronic Systems; (2) Engine Management System (EMS); (3) Chassis Management System (CMS); (4) Comfort, Safety, and Information Technology (CSIT); and (5) Vehicle Control System (VCS). Furthermore, these five main clusters are divided into 47 main functions and later developed into 101 basic functions further elaborated into several CUs. As this study focuses on the VCS cluster, the results are expected to unveil the link and match of autrotonic engineering competencies trained at VSs with those expected by ASI and the relevancy of both.

\section{METHODOLOGY}

This study is quantitative in nature, and it employed a survey method to achieve its aims, formulating the relevance of ASI needs of the autotronic competencies in the VCS cluster with those learned at VSs. The research paradigm underlying the study is presented in Figure 2. Respondents in this study were purposefully selected, namely owners, managers, heads of workshops, service managers of 10 ASI and three educators from VSs. The aforementioned ASI consists of the general/custom service industries and brand-holder sole distributors (ATPMs) with details as described in Table 1. 
Automotive Service Industry Needs of Autotronic Competencies and those Prepared by the Education

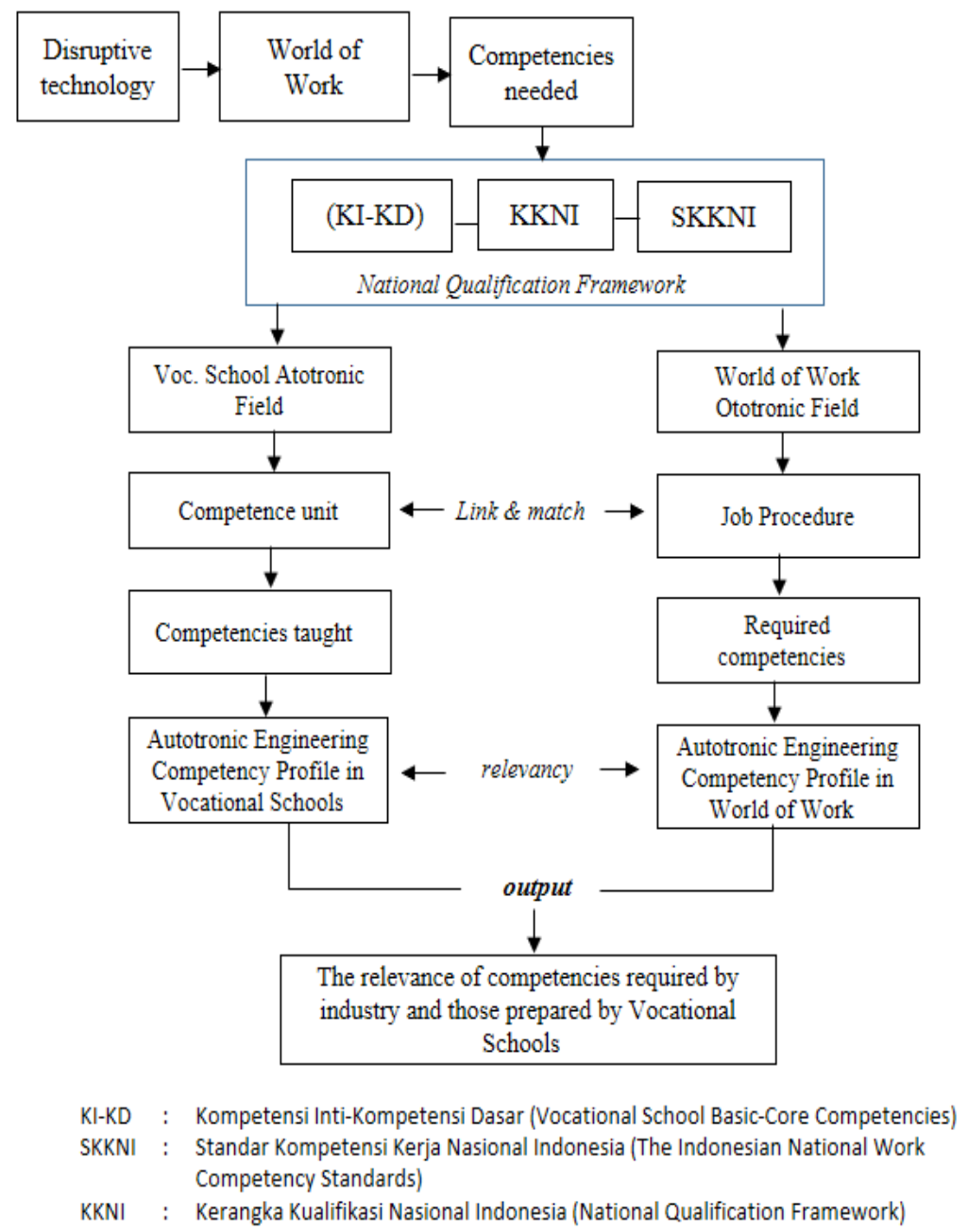

Figure 2 The research paradigm

Data were collected through include close-ended questionnaires, structured interviews, observations, and document studies. The questionnaires adopted a Guttman scale with a score of 0 and 1. Respondents from ASI responded to the questionnaire by considering the extent to which the competency items possessed by The Autotonic Engineering Expertise Competencies (TOTR) graduates listed were needed by the workforce. Respondents from VSs, likewise, were asked to fill in the questionnaire based on whether the listed CUs are taught to TOTR students. The questionnaire was then distributed to respondents using the principles of the Delphi Technique [5]. Each respondent, without knowing the identity of each other, was asked to fill out a questionnaire in the form of a checklist.

Besides, the questionnaire was prepared based on the synthesis of CUs from SKKNI, $\mathrm{KKNI}$, and KI-KD of the autotronics engineering. Interviews, observations, and document studies in this study were conducted to strengthen the data analysis results from the questionnaire. The validation of the research instrument was carried out by expert judgment [22] [23]. Alpha coefficient of 0.970 indicates that the instrument, in the form of a questionnaire used in this study, is reliable [24] [25]. 
Wagiran and Yudha Ari Purnama

Table 1 Research respondents

\begin{tabular}{cllc}
\hline NO & \multicolumn{1}{c}{ Work Unit } & \multicolumn{1}{c}{ Position } & Category \\
\hline 1 & Automotive Service Industry & Service Manager & ATPM \\
2 & & Head of the Workshop & ATPM \\
3 & Service Advisor & ATPM \\
4 & Owner & Custom \\
5 & Manager & Custom \\
6 & Service Manager & ATPM \\
7 & Owner & Custom \\
8 & Owner & Custom \\
9 & & Instructor & ATPM \\
10 & & Head of the Workshop & ATPM \\
11 & Vocational School & Teacher/Instructor & Education \\
12 & & Teacher/Instructor & Education \\
13 & & Teacher/Instructor & Education \\
\hline
\end{tabular}

The data in this study were analyzed descriptively. CUs are considered needed by the automotive service industry or taught by VSs if the unit item's percentage is higher than or the same as $(\geq)$ the mean, and they are considered 'not needed or not taught' by both parties if the percentage of the items is less than $(<)$ the mean.

\section{RESULTS AND DISCUSSION}

\subsection{The Formulation of Middle-Level Employee Competencies in Autotronics}

The formulation of mid-level workforce competencies in autotronics is compiled by synthesizing three guidelines that apply nationally.

a. The Decree of the Minister of Manpower No. 167 of 2019 concerning the Determination of National Work Competency Standards in the Wholesale and Retail Trade Category; Repair and Maintenance of Cars and Motorbikes in the Main Group of Trade, Repair and Maintenance of Cars and Motorbikes in the Automotive Engineering Sub-sector in the Automated Engineering Field.

b. Level II Certification Scheme of KKNI in the Competency of Autotronics Engineering.

c. KI-KD (Basic-Core Competence) in Autotronics Engineering

The synthesis results of the three guidelines as the competencies of middle-level employees in autotronics combined with their competency level [26] are presented in Table 2.

The results of the synthesis of the three guidelines in Table 2 are references for employees who want to improve their careers and vocational students in completing the competencies they learn before entering the workforce, including prospective VS graduates. The formulation can be used as a benchmark to assess the needs of competencies in the world of work, specifically autotronics, with various changes and as an effort to improve the national standards as stated by Beaumont [27] ". there is a need for the national standards to be updated". 
Automotive Service Industry Needs of Autotronic Competencies and those Prepared by the Education

Table 2 Middle-level employee competencies in autotronics

\begin{tabular}{|c|c|c|}
\hline Main Competency & Competence Unit & Competency Level \\
\hline Electronic Control & Identify components ... & C2 (Understand) \\
\hline \multirow[t]{6}{*}{ Unit (ECU) System } & Understand the working principle ... & \\
\hline & $\begin{array}{l}\text { Simulate work ... on the practice board } \\
\text { Assemble a circuit ... on a car }\end{array}$ & C3 (Apply) \\
\hline & $\begin{array}{l}\text { Measure the amount of electric power of } \\
\text { components ... }\end{array}$ & C4 (Analyse) \\
\hline & Diagnose damage that occurs to ... & \\
\hline & Repair damage to ... & C3 (Apply) \\
\hline & Test the performance of... & C5 (Evaluate) \\
\hline \multirow{8}{*}{$\begin{array}{l}\text { In-Vehicle } \\
\text { Networking System } \\
\text { (IVNS) }\end{array}$} & Parsing types of Scantool communication data & C2 (Understand) \\
\hline & $\& \ldots$ & \\
\hline & $\begin{array}{l}\text { Translate Scantool real time communication } \\
\text { data with ... }\end{array}$ & \\
\hline & $\begin{array}{l}\text { Operate communication data between Scantool } \\
\text { and ... }\end{array}$ & C3 (Apply) \\
\hline & $\begin{array}{l}\text { Analyze Scantool real time communication } \\
\text { data with ... }\end{array}$ & C4 (Analyse) \\
\hline & Diagnose damage to ... & \\
\hline & Repair damage to ... & C3 (Apply) \\
\hline & Test the performance of ... & $\mathrm{C} 5$ (Evaluate) \\
\hline Fundamental & Understand various types of microcontrollers & $\mathrm{C} 1$ (Remember) \\
\hline \multirow[t]{6}{*}{$\begin{array}{l}\text { Control System for } \\
\text { Automotive (FCSA) }\end{array}$} & $\begin{array}{l}\text { Understand microcontroller block diagrams on } \\
\text { a car ECU }\end{array}$ & $\mathrm{C} 2$ (Understand) \\
\hline & $\begin{array}{l}\text { Present the microcontroller block data diagram } \\
\text { on a car ECU }\end{array}$ & C3 (Apply) \\
\hline & $\begin{array}{l}\text { Design a circuit drawing ... based on a } \\
\text { microcontroller }\end{array}$ & \\
\hline & $\begin{array}{l}\text { Assemble a microcontroller-based circuit on a } \\
\text { car }\end{array}$ & \\
\hline & $\begin{array}{l}\text { Analyze the performance of microcontroller- } \\
\text { based circuits }\end{array}$ & C4 (Analyse) \\
\hline & $\begin{array}{l}\text { Test the work of a circuit ... based on a } \\
\text { microcontroller }\end{array}$ & C5 (Evaluate) \\
\hline \multirow{7}{*}{$\begin{array}{l}\text { Develop and Modify } \\
\text { Vehicle Control } \\
\text { System (VCS) }\end{array}$} & Explain how a downloader operates & $\mathrm{C} 2$ (Understand) \\
\hline & Identify the flowchart on a car ECU & \\
\hline & Make a flowchart on a car ECU & C3 (Apply) \\
\hline & $\begin{array}{l}\text { Translate the flowchart that was created } \\
\text { Analyze microcontroller-based ECU } \\
\text { simulators }\end{array}$ & C4 (Analyse) \\
\hline & Develop a program and do flashing & C3 (Apply) \\
\hline & $\begin{array}{l}\text { Test the performance of a microcontroller- } \\
\text { based ECU simulators }\end{array}$ & $\mathrm{C} 5$ (Evaluate) \\
\hline & $\begin{array}{l}\text { Develop, make \& apply electronic } \\
\text { modifications to VCS }\end{array}$ & C6 (Create) \\
\hline
\end{tabular}

\subsection{Mid-Level Employee Competencies in Autotronics as Required by the Automotive Services Industry}

A description of the competency profile of the VCS cluster required by the workforce as obtained from ten different automotive service industries were collected. The research data 
were then processed to find out and determine which items of competency are needed and not needed by the world of work. Based on the analysis of these data, the autotronic competencies in the VCS cluster needed by the world of work can be formulated as follows.

a. Electronic Control Unit (ECU) System

1) Identify components

2) Understand the working principle

3) Measure the amount of electric power of ECU components

4) Diagnose damage to the ECU

5) Test the performance of the ECU

b. In-Vehicle Networking System (IVNS)

1) Parse communication data types on Scantool and IVNS

2) Translate real time Scantool and IVNS communication data

3) Operate communication data between Scantool and IVNS

4) Analyze real-time communication data from Scantool and IVNS

5) Test the IVNS performance

c. Fundamental Control System for Automotive (FCSA)

1) Understand various types of microcontrollers

2) Understand microcontroller block diagrams on a car ECU

3) Analyze the performance of microcontroller-based FCSU circuits

d. Develop and Modify Vehicle Control System

1) Analyze a flowchart on a car ECU

2) Develop programs and do flashing

Based on these data, it is obvious that from 30 competencies in the VCS cluster of the autotronic field, 15 CUs are greatly required by ASI. Meanwhile, as many as 15 CUs are not needed. This is invaluable information for the world of work and the world of education to design the education process according to the needs of the workforce.

\subsection{The Relevance of Mid-Level Employee Competencies in Autotronics required by the Automotive Service Industry with Those Taught at Vocational Schools}

VCS cluster autotronic competencies cover 30 basic competency items which are divided into 4 main competency categories as in Table 2 . The results of the analysis of the relevance of the competencies needed by ASI with those taught in VSs can be seen in Figure 2. Based on the data in Figure 2, it can be observed that from 30 competency items obtained: (1) 4 competency units are both needed by ASI and taught at VSs; (2) there is 1 unit of competency taught at VSs but not required by the ASI; (3) 11 competency units are required by ASI, but they are not trained in VSs; and lastly (4) there exist 14 competency units neither needed by ASI nort taught at VSs. The percentage of the relevance of competency items obtained in the VCS cluster is $27 \%$, which is in the low category.

Based on the interviews, respondents from vocational schools stated that the competency units which are not included in the present school curriculum do not necessarily mean that they will not be taught later, but rather currently the schools face limitations on both the teachers and learning facilities. Likewise, a statement from ASI explaining that the missing competency units on their parts do not mean that the competency items are not required at all. Rather, the competencies are felt to be of high-level to be fully studied and mastered by TOTR fresh graduates. In general, especially at ATPMs, new workers will be given more 
training from the basics and adjusted to the characteristics of the ATPMs' workshops in which they work.

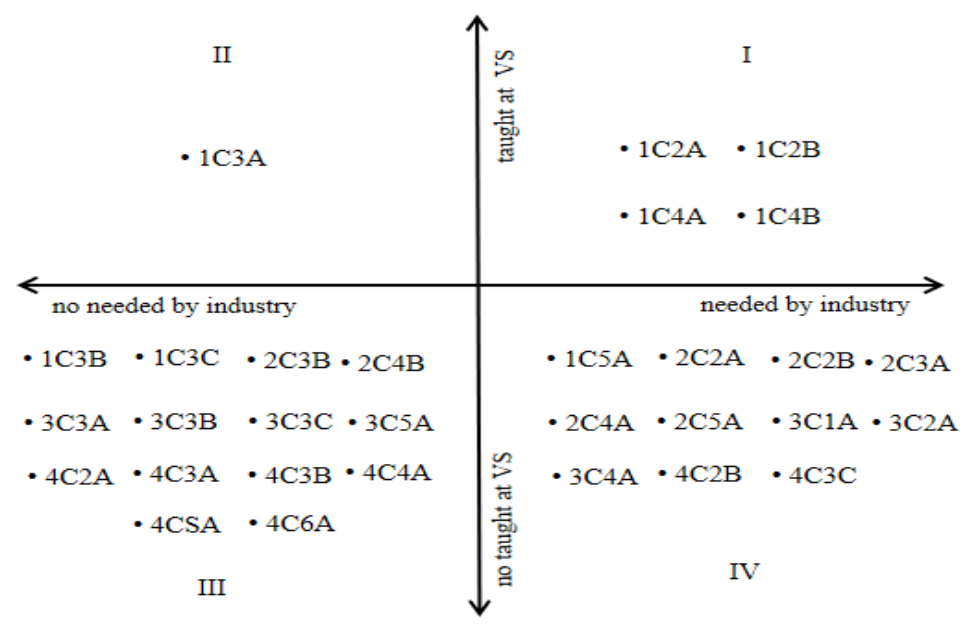

Figure 2 The relevance of autotronic competencies in the VCS Cluster

This is unlike the automotive custom service industry or non-ATPMs which tend to require graduates, even fresh graduates, to have more competencies with the broader scope. This industry is not tied to a particular car brand, so these graduates should be able to handle cars from various existing car brands. In addition, It generally also does not provide a training system for their new workforce, so they tend to expect VS graduates with better and wider scope of competencies.

The relevance between the world of education, especially VSs, and the industry, should be gradually improved. Technology from every field of work continues to experience changes and developments in order to meet the desires and ease of human activities. Of course in the future there will be great innovations in the field of automotive engineering with more futuristic features embedded in new vehicles that will continue to be launched.

This study found that the relevance of the autotronic competencies in the VCS cluster required by the ASI with those taught in VSs is still relatively low. Several studies [28] [15] [29] [30] show the same results, namely the industry and education sectors still experience the mismatch between competencies needed and prepared. Therefore, various efforts need to be taken so that the gap between them gets smaller. Hollander and Mar [31] state that VE does not merely play its role to train and teach students to get stable jobs, but also to produce graduates who are innovative and able to develop and adapt to changes in the surrounding environment, especially in the world of work.

Relevance is also an important aspect for the workforce to adapt to various changes. This is in line with Billet [10] that VE aims to provide students with preparation and understanding of working life so that they can develop the skills needed as workers according to the chosen field, in this case autotronics. The importance of relevance is also in line with Dewey [32] who states that VE institutions should not merely provide technical preparation for the industries and professions as they now operate, much less by merely reproducing existing industrial conditions in schools. The problem is not that of making the schools an adjunct to manufacturing and commerce, but of utilizing the factors of industry to make school life more active, more full of immediate meaning and more connected with out-of-school experience.

In short, the philosophy of VE is matching what job is needed and what is needed to do the job [33], and it acts as a vehicle to meet employment needs in a country [34]. Cooperation between the world of industry, the world of education, and the government as the holder of 
regulations is really essential to be strengthened so that synergistic cooperation occurs to realize the link and match of the world of work with that of education.

\section{CONCLUSION}

Based on the analysis of the competency relevance, it is obtained that of 30 autotronic competency units in the VCS cluster, (1) 4 of them are both taught in VSs and needed by ASI; (2) $1 \mathrm{CU}$ is taught in VSs but not required by ASI; (3) 11 CUs are not taught in VSs, but are needed by ASI; and (4) 14 CUs are neither taught in VSs nor required by the automotive service industry. The relevance of the autotronics engineering competency profile provides all-important information to improve learning in VSs according to what the working world expects.

\section{REFERENCES}

[1] Schwab, K. The Forth Industrial Revolution. Switzerland: World Economic Forum, 2016, pp. 7.

[2] World Economic Forum. The fourth industrial revolution, by Klaus Schwab. https://www.weforum.org/about/the-fourth-industrial-revolution-by-klaus-schwab.

[3] Advanced Industries. The Road to 2020 and Beyond: What's Driving the Global Automotive Industry? Stuttgart: McKinsey \& Company, Inc., 2013, pp.14.

[4] IBM Institute for Business Value. Automotive 2025: Industry without Borders - Engage with Consumers, Embrace Mobility and Exploit the Ecosystem. New York: IBM Corporation, 2015, pp.9.

[5] Finch, C. R. and Crunkilton, J. R. Curriculum Development in Vocational and Technical Education - Planning, Content, and Implementation. Boston: Allyn and Bacon, 1999, pp.14.

[6] Asian Development Bank. Education and Skills-Strategies for Accelerated Development in Asia and the Pacific. Manila: ADB, 2008, pp.25.

[7] Pavlova, M. Technology and Vocational Education for Sustainable DevelopmentEmpowering Individuals for the Future. Queensland: Springer, 2009, pp. 7.

[8] Sudira, P. TVET Abad XXI-Filosofi, Teori, Konsep, dan Strategi Pembelajaran Vokasional. Yogyakarta: UNY Press, 2016, pp.7.

[9] United Nations Educational, Scientific, and Cultural Organization. Technical and Vocational Education and Training for the Twenty-first Century-UNESCO Recommendations. Paris: UNESCO, 2001, pp. 7.

[10] Billet, S. Vocational Education-Purposes, Traditions and Prospects. Queensland: Springer, 2011, pp. 59.

[11] Trilling, B., \& Fadel, C. 21st Century Skills: Learning for Life in Our Times. San Francisco, CA: John Wiley \& Sons, 2009, pp. 48.

[12] Sudira, P. Metodologi Pembelajaran Vokasional Abad XXI. Yogyakarta: UNY Press, 2018, pp. 26-37.

[13] Ministry of Education and Culture of the Republic of Indonesia. Revitalisasi Pendidikan Vokasi. Jakarta: Kemdikbud, 2016, pp. 1-13.

[14] The Statistics Indonesia., Berita resmi statistic (2019), 8 Desember 2019, www.bps.go.id/website/materi_ind/materiBrsInd-20191105114507.pdf.

[15] Puspitasari, S. Educational Mismatch dan Pengaruhnya terhadap Pendapatan Lulusan Sekolah Menengah Kejuruan di Indonesia. Konferensi Nasional Ilmu Administrasi, 1,9, 2019, pp. 1-8. 
[16] MacKenzie, J., and Polvere, R.-A. TVET Glossary: Some Key Terms. In: R. Maclean, R. and Wilson, D. N., ed., International Handbook of Education for the Changing World of Work - Bridging Academic and Vocational Learning. Bonn: Springer, 2009, pp. 63-73.

[17] International Labour Organization. Regional Model Competency Standards: Core Competencies. Bangkok: ILO, 2015, pp. ix.

[18] Zhao, Z. Competence Research. In: Zhao, Z. and Rauner, F., ed., Areas of Vocational Education Research. Berlin: Springer, 2014, pp. 167-177.

[19] Lucas, B., Spencer, E., and Claxton, G. How To Teach Vocational Education: A Theory of Vocational Education. London: The City and Guilds of London Institute, 2012, pp. 38.

[20] DeSeCo Project. The Definition and Selection of Key Competencies-Executive Summary. OECD, 2005, pp. 4.

[21] Gagnon, R. (2009). Competency, Meaningful Learning and Learning Styles in TVET. In: R. Maclean, R. and Wilson, D. N., ed., International Handbook of Education for the Changing World of Work - Bridging Academic and Vocational Learning. Bonn: Springer, 2009, pp. 2697-9.

[22] Ary, D., Jacobs, L. C., Sorensen, C., and Razavieh, E. Introduction to Research in Education ( $8^{\text {th }}$ Edition). Belmont: Wadsworth., 2010, pp. 224-236.

[23] Gay, L.R. Educational Research. London: Charles E. Merril Publishing Co, 1981, pp. 112.

[24] Coakes, S. J., and Steed, L. G. SPSS for Windows: Analysis without Anguish. New York: John Wiley \& Sons, 1996, pp. 118.

[25] Isaac, S., and Michael, W. B. Handbook in Research and Evaluation. California: Edits Publisher, 1984, pp. 125-127.

[26] Anderson, L.W., and Krathwohl, D.R. A Taxonomy for Learning, Teaching, and Assesing: A Revision of Bloom's Taxonomy of Educatioanl Objectives. New York: Addison Wesley Longman, Inc., 2001.

[27] Beaumont, G. Review of 100 NVQs and SVQs -A Report Submitted to the Department for Education and Employment. Chesterfield: NCVQ/SCOTVEC, 1995, pp. 12.

[28] Kurniawan, A. W., Erda, G. and Majid, M.A. Profil lulusan SMK terhadap tingkat penyerapan tenaga kerja di Indonesia Tahun 2018/2019. Vocational Education Policy, 1, 9, 2019, pp. 1-16.

[29] Muljono, P. Kajian relevansi kurikulum smk dengan kebutuhan pengembangan teknologi masa depan indonesia. Jurnal Penyuluhan, 2(3), 2006, pp. 1-28.

[30] Fakhri, E., and Yufridawati. Relevansi kompetensi dan tingkat daya saing lulusan smk dalam dunia kerja (studi kasus pada smk teknik otomotif di empat kabupaten/kota). Repositori Kemendikbud, 2017, pp. 1-18. http://repositori.kemdikbud.go.id.

[31] Hollander, A., and Mar, N. Y. Towards Achieving TVET for All: The Role of the UNESCO-UNEVOC International Centre for Technical and Vocational Education and Training. In: R. Maclean, R. and Wilson, D. N., ed., International Handbook of Education for the Changing World of Work - Bridging Academic and Vocational Learning. Bonn: Springer, 2009, pp. 41-43.

[32] Kumar, K. An Introduction to the Philosophy of Education. Delhi: Aakar Books, 2004, pp. 340.

[33] Thompson, J.F. Foundations of Vocational Education: Social and Philosophical Concepts. New Jersey: Prentice-Hall, 1973, pp. 203-230.

[34] Rojewski, J. W. (2009). A Conceptual Framework for Technical and Vocational Education and Training. In: R. Maclean, R. and Wilson, D. N., ed., International Handbook of Education for the Changing World of Work - Bridging Academic and Vocational Learning. Bonn: Springer, 2009, pp. 19-22. 